\title{
Management Analysis of Infection Prevention: Nurses' Compliance in Implementing Hand Hygiene in the Inventories of Rantauprapat Hospital
}

\author{
Ferdiana Casanova Daulay ${ }^{1}$, Sudiro $^{1}$, Asriwati Amirah ${ }^{1}$ \\ ${ }^{I}$ Faculty of Public Health, Institut Kesehatan Helvetia, Indonesia. \\ ${ }^{2}$ Faculty of Public Health, Institut Kesehatan Helvetia, Indonesia \\ ${ }^{3}$ Faculty of Public Health, Institut Kesehatan Helvetia, Indonesia.
}

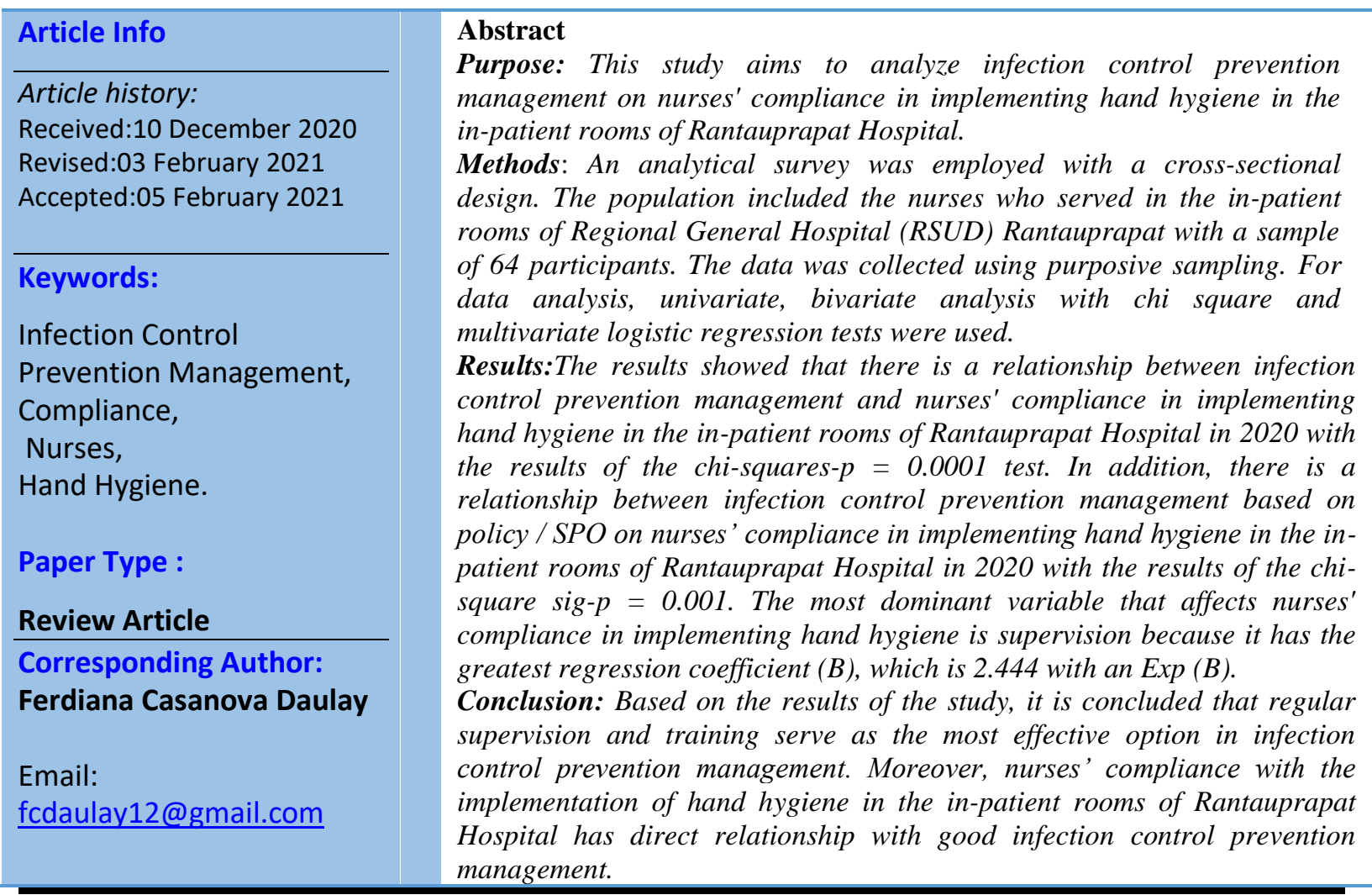

\section{Introduction}

Hand hygiene is an effort to prevent infection that is transmitted through the hands by removing dirt and debris and inhibiting or killing microorganisms on the skin that can be obtained from contact between the patient and the environment (DepKes, 2008). Contaminated hands are a major cause of transmission of infection. Failure to practice proper hand hygiene is a major cause of nosocomial infection and the spread of multi-resistant microorganisms in health care facilities (Trampuz et al., 2004; Tavolacci et al., 2008). Nurses have a considerable influence on the occurrence of nosocomial infections because nurses are health workers who have the most contact with patients and interact directly with patients for 
24 hours. Efforts to prevent nosocomial infections that can be carried out by nurses are to increase the ability to apply standard precautions with its main component which is one of the most effective methods to prevent the transmission of pathogens related to health services by practicing hand hygiene (Manojlovich \& DeCicco, 2008; Safety \& World Health Organization, 2009).

Prevention and control of nosocomial infections in hospitals is very important because the incidence of nosocomial infections reflects the quality of hospital services. The risk of infection in the hospital can be minimized by planning, implementing, coaching, education and training, monitoring and evaluation. Infection prevention and control can be done by breaking the chain of transmission. The components of the infection transmission chain, namely starting from the infectious agent, reservoir, exit door, mode of transmission, entrance and host. Nurses are included in the components of the infection transmission chain and can be included in vulnerable hosts and places where the agent causing the infection grows (Beggs, 2003; Hinkle \& Cheever, 2018; Suleyman et al., 2018). A nurse who is in a state of decreased immunity has the potential for infection while working, so the nurse needs to use personal protective equipment (PPE) when taking action on patients. One of the effects of not using personal protective equipment (gloves and masks) while working is getting a nosocomial infection.

The results of the preliminary study conducted by the researchers in the Intensive Care Unit of the Rantauprapat Hospital on November 28, 2019 to December 3, 2019 by observing the nurses who performed hand hygiene, found that $75 \%$ of the nurses had not performed hand hygiene according to the prescribed procedure and $70 \%$ of the nurses had their knowledge regarding hand hygiene is still not good. The socialization of hand washing has been carried out by IPCN and the management every day and at the morning apple every Wednesday, a hand washing demonstration was held in front of all Rantauprapat Hospital staff, only $35 \%$ were able to demonstrate correctly and correctly. The management has also facilitated tools such as sinks in each unit, which is $50 \%$ in good condition. Provision of a hand drub in each unit and in all waiting rooms, $45 \%$ are used by nurses when examining patients. Leaflets as information media and as a guide for nurses to perform hand hygiene, $35 \%$ of nurses who read the leaflets in their respective rooms.

Based on the incident data above and to maintain the safety of patients, visitors, nurses, other health workers in order to improve the quality of the hospital, the researchers are interested in analyzing infection control prevention management on nurse compliance in implementing hand hygiene in the inpatient room of Rantauprapat Hospital in 2020.

\section{Methodology and Procedures}

This study used an analytical survey with a cross sectional design. The population included the nurses who served in the in-patient rooms of Regional General Hospital (RSUD) of Rantauprapat with a sample of 64 participants. The data was collected using purposive sampling technique. A questionnaire was used as an instrument for collecting demographic data and information regarding infection control management (PPI). This instrument was tested using validity and reliability tests at the Dr. Pringadi Regional General Hospital, and it obtained valid results with $>0.444$. It was declared reliable with Cronbach negligent results $>$ 0.944. 
Data collection was carried out after obtaining permission from the relevant authorities. The researchers looked for potential respondents with inclusion and exclusion criteria then explained to prospective respondents about the objectives, benefits, and assisted them on how to fill out the questionnaire. After obtaining informed consent, the respondents were allowed to fill out a questionnaire or read it by the researcher and give the respondents the opportunity to have questions. After all the data in the questionnaire were collected, analysis was carried out through several stages, starting from checking the completeness of the data (editing), providing code (coding), ensuring that the data was clean from errors (cleaning), and measuring each respondent's answer by looking for a percentage (tabulating) which is then presented in the form of a frequency distribution table.

\section{Results and Discussion}

Table 1. Frequency distribution based on the characteristics of respondents at the 2020 Rantauprapat Regional Hospital $(n=64)$

\begin{tabular}{lcc}
\hline \multicolumn{1}{c}{ Respondent Characteristics } & $(\mathrm{F})$ & $(\%)$ \\
\hline Sex & & \\
$\quad$ Male & 12 & 18,8 \\
$\quad$ Female & 52 & 81,3 \\
Age & & \\
$\quad$ 26-35 years & 50 & 78,1 \\
$\quad$ 36-45 years & 11 & 17,2 \\
$\quad$ 46-55 years & 3 & 4,7 \\
Education & & \\
$\quad$ Diploma in Nursing & 30 & 46,9 \\
$\quad$ Bachelor in Nursing & 34 & 53,1 \\
Years of Service & & \\
$\quad \leq 10$ Years & 44 & 68,8 \\
$\quad$ 11-19 Years & 20 & 31,3 \\
$\quad$ & & \\
\hline
\end{tabular}

The results showed that the majority of respondents were female, namely 52 people $(81.3 \%)$, age range $26-35$ years as many as 50 people (78.1\%), S1 Nursing education as many as 34 people $(53.1 \%)$. working $\leq 10$ years as many as 44 people $(68.8 \%)$.

Table 2. Dfrequencydistributionbasedonthecharacteristicsofrespondentsat RSUD

\begin{tabular}{lcc}
\multicolumn{3}{c}{ Rantauprapat $2020(\mathrm{n}=64)$} \\
\hline Variable & $\mathrm{F}$ & $\%$ \\
\hline Infection Control Management & & \\
& & \\
Insufficient & 29 & 45,3 \\
$\quad$ Good & 35 & 54,7 \\
Regulation/SPO & &
\end{tabular}




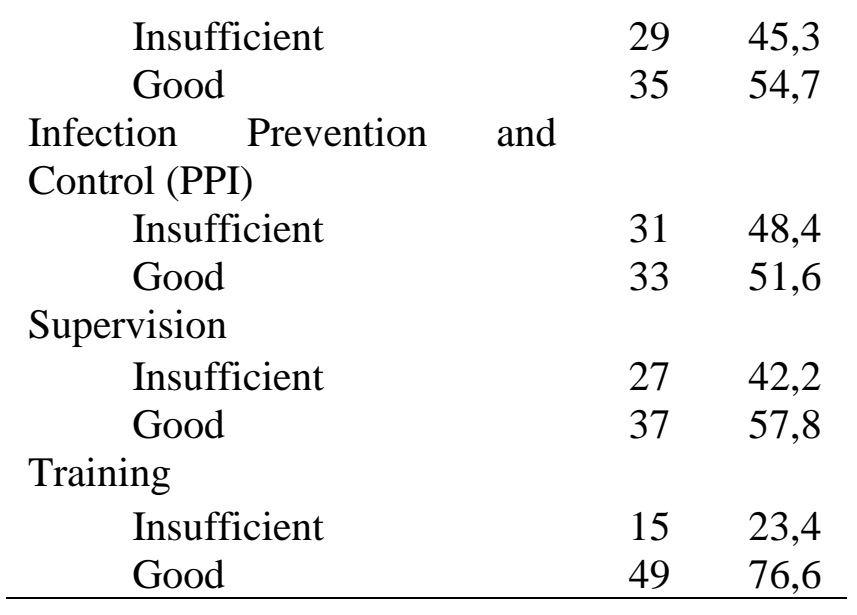

The results of this study found that the infection control prevention management was in the poor category, namely 29 people $(45.3 \%)$ and good, namely 35 people $(54.7 \%)$, the regulation / SPO was in the poor category, namely 29 people (45.3\%) and good namely 35 people (54.7\%), Infection Prevention and Control (PPI) in the poor category, namely 31 people $(48.4 \%)$ and good, namely 33 people $(51.6 \%)$, the poor category of supervision, namely 27 people $(42,2 \%)$ and good, namely 37 people $(57.8 \%)$, and for the less category of training, namely 15 people (23.4\%) and good, namely 49 people (76.6\%).

Table 3. Relationship between Infection Control Prevention Management and Respondents' Compliance in Implementing Hand Hygiene

\begin{tabular}{|c|c|c|c|c|}
\hline \multirow[b]{2}{*}{ Obedience } & \multicolumn{3}{|c|}{ PPI Management } & \multirow{2}{*}{$\begin{array}{c}P \\
\text { Value }\end{array}$} \\
\hline & $\begin{array}{c}\text { Insuffici } \\
\text { ent }\end{array}$ & Good & Total & \\
\hline Obedient & $\begin{array}{c}5 \\
(17,2 \%) \\
\end{array}$ & $\begin{array}{c}28 \\
(80 \%) \\
\end{array}$ & $\begin{array}{c}33 \\
(51,6 \%) \\
\end{array}$ & \multirow[t]{3}{*}{0,0001} \\
\hline Not Obedient & $\begin{array}{c}24 \\
(82,8 \%) \\
\end{array}$ & $\begin{array}{c}7 \\
(20 \%) \\
\end{array}$ & $\begin{array}{c}31 \\
(48,4 \%) \\
\end{array}$ & \\
\hline Total & $\begin{array}{c}29 \\
(100 \%)\end{array}$ & $\begin{array}{c}35 \\
(100 \%)\end{array}$ & $\begin{array}{c}64 \\
(100 \%) \\
\end{array}$ & \\
\hline
\end{tabular}

It was found that $82.8 \%$ of respondents who were not compliant stated that PPI management was not good and this percentage was greater than $80 \%$ of respondents who complied and stated that PPI management was good. The results of the chi-square test sig- $\mathrm{p}=$ 0.0001 or $<$ value $\alpha=0.05$ means that there is a relationship between infection control prevention management and the compliance of respondents in implementing hand hygiene in the inpatient room of Rantauprapat Hospital in 2020.

Table 4. ManagementRelationshipofInfectionControlPreventionBasedonRegulation / SPO onRespondents' Compliance in ImplementingHandHygiene

\begin{tabular}{|l|c|c|c|c|}
\hline \multirow{2}{*}{ Obedience } & \multicolumn{2}{|c|}{ PPI Management based on Regulation / } & \multirow{2}{*}{ P Value } \\
\cline { 2 - 4 } & Insufficient & Good & Total & \\
\hline Obedient & $8(27,6 \%)$ & $25(71,4 \%)$ & $33(51,6 \%)$ & \multirow{2}{*}{0,001} \\
\hline Not Obedient & $21(72,4 \%)$ & $10(28,6 \%)$ & $31(48,4 \%)$ & \\
\hline
\end{tabular}


It was found that $72.4 \%$ of respondents who were not compliant stated that PPI management based on regulations / SPO was not good and this percentage was greater than $71.4 \%$ of respondents who complied and stated that PPI management based on regulation / SPO was good. The results of the chi-square test show that sig-p $=0.001$ or $<$ value $\alpha=0.05$ means that there is a relationship between infection control prevention management based on regulations / SPO on the compliance of respondents in implementing hand hygiene in the inpatient room of Rantauprapat Hospital in 2020.

Table 5. Relationship of Infection Control Prevention Management Based on Infection Prevention and Control (PPI) Against Respondents' Compliance in Implementing Hand Hygiene

\begin{tabular}{|l|c|c|c|c|}
\hline \multirow{2}{*}{ Obedience } & \multicolumn{2}{|c|}{ PPI management based on PPI } & \multirow{2}{*}{ P Value } \\
\cline { 2 - 4 } & Insufficient & Good & Total & \\
\hline Obedient & $6(19,4 \%)$ & $27(81,8 \%)$ & $33(51,6 \%)$ & \multirow{2}{*}{0,0001} \\
\hline Not Obedient & $25(80,6 \%)$ & $6(18,2 \%)$ & $31(48,4 \%)$ & \\
\hline Total & $31(100 \%)$ & $33(100 \%)$ & $64(100 \%)$ & \\
\hline
\end{tabular}

It was found that $80.6 \%$ of respondents who were not compliant stated that PPI management based on PPI was not good and this percentage was smaller than $81.8 \%$ of respondents who complied and stated that PPI management based on PPI was good. The results of the chi-square test show that sig-p $=0.0001$ or $<$ value $\alpha=0.05$ means that there is a relationship between infection control prevention management based on Infection Prevention and Control (PPI) to the compliance of respondents in implementing hand hygiene in the inpatient room of Rantauprapat Hospital.

Table 6. Relationship Management of Infection Control Prevention Based on Supervision of Respondents' Compliance in Implementing Hand Hygiene

\begin{tabular}{|l|c|c|c|c|}
\hline \multirow{2}{*}{ Obedience } & \multicolumn{2}{|c|}{ PPI Management based on Supervision } & \multirow{2}{*}{$\boldsymbol{P}$ Value } \\
\cline { 2 - 4 } & Insufficient & Good & Total & \\
\hline Obedient & $6(22,2 \%)$ & $27(73 \%)$ & $33(51,6 \%)$ & \multirow{2}{*}{0,0001} \\
\hline Not Obedient & $21(77,8 \%)$ & $10(27 \%)$ & $31(48,8 \%)$ & \\
\hline Total & $27(100 \%)$ & $37(100 \%)$ & $64(100 \%)$ & \\
\hline
\end{tabular}

Table 7. Relationship Management of Infection Control Prevention Based on Training on Respondents' Compliance in Implementing Hand Hygiene

\begin{tabular}{|l|c|c|c|c|}
\hline \multirow{2}{*}{ Obedience } & \multicolumn{2}{|c|}{ PPI Management based on Training } & \multirow{2}{*}{ P Value } \\
\cline { 2 - 4 } & Insufficient & Good & Total & \\
\hline Obedient & $2(13,3 \%)$ & $31(63,3 \%)$ & $33(51,6 \%)$ & \multirow{2}{*}{0,001} \\
\hline Not Obedient & $13(86,7 \%)$ & $18(36,7)$ & $31(48,4 \%)$ & \\
\hline Total & $15(100 \%)$ & $49(100 \%)$ & $64(100 \%)$ & \\
\hline
\end{tabular}

It was found that $86.7 \%$ of respondents who were not compliant stated that PPI management was based on poor training and this percentage was greater than $63.3 \%$ of respondents who complied and stated that PPI management was based on good training. The 
results of the chi-square test show that sig-p $=0.001$ or $<$ value $\alpha=0.05$ means that there is a relationship between infection control prevention management based on training on respondent compliance in implementing hand hygiene in the inpatient room of Rantauprapat Hospital in 2020.

Table 8. Step I Logistic Regression Test Results

\begin{tabular}{|c|c|c|c|c|c|c|}
\hline \multirow[t]{2}{*}{ No } & \multirow{2}{*}{$\begin{array}{c}\text { Independent } \\
\text { Variable }\end{array}$} & \multirow[b]{2}{*}{$\mathrm{B}$} & \multirow[b]{2}{*}{ Sig } & \multirow[b]{2}{*}{$\operatorname{Exp}(B)$} & \multicolumn{2}{|c|}{ 95\% C.I.for $\operatorname{EXP}(B)$} \\
\hline & & & & & Lower & Upper \\
\hline 1 & $\begin{array}{l}\text { Infection Control } \\
\text { Prevention } \\
\text { Management }\end{array}$ & -0.117 & 0.909 & 0.889 & 0.119 & 6.636 \\
\hline 2 & Regulation & 1.631 & 0.070 & 5.110 & 0.873 & 29.909 \\
\hline 3 & $\begin{array}{l}\text { Infection Control } \\
\text { Prevention (PPI) }\end{array}$ & 2.302 & 0.013 & 9.997 & 1.620 & 61.672 \\
\hline 4 & Supervision & 2.092 & 0.032 & 8.104 & 1.204 & 54.563 \\
\hline 5 & Training & 1.475 & 0.251 & 4.370 & .351 & 54.331 \\
\hline & Constant & -4.319 & 0.002 & 0.013 & & \\
\hline
\end{tabular}

In step I logistic regression using the enter method it is known that infection control prevention management $(0.909>0.05)$ and training $(0.251>0.05)$ so that these two variables are excluded in step II. Therefore, step II logistic regression was carried out using the enter method with regulatory variables, Infection Control Prevention (PPI), supervision.

Table 9. Step II LogisticRegressionTestResults

\begin{tabular}{|c|l|c|c|c|}
\hline No & Independent Variable & B & Sig & $\operatorname{Exp(B)}$ \\
\hline 1 & Regulation & 1.384 & 0.088 & 3.990 \\
\hline 2 & $\begin{array}{l}\text { Infection Control } \\
\text { Prevention (PPI) }\end{array}$ & 2.396 & 0.002 & 10.980 \\
\hline 3 & Supervision & 2.444 & 0.002 & 11.520 \\
\hline & Constant & -3.256 & 0.000 & 0.039 \\
\hline
\end{tabular}

From the results of the multivariate test using logistic regression using the enter method in step II which has the greatest effect is supervision because it has the greatest regression coefficient (B), which is 2,444 with an Exp (B) value of 11,520, meaning that the head of the room carries out category supervision. Good for the compliance of respondents in implementing hand hygiene 11,520 times the chance of respondents obeying in implementing hand hygiene compared to the head of the room who carried out supervision of the less category of respondents' compliance in implementing hand hygiene. 


\section{Discussion}

The analysis of data reveals that there is an effect of infection control prevention management on nurses' compliance in implementing hand hygiene. This is because nurses in the hospital are guided to carry out infection control prevention management in the good category. Although the majority is good, there are nurses who are lacking in infection control prevention management. This is due to the compliance of nurses in implementing hand hygiene in the category of not obedient $85.2 \%$ and obedient $14.8 \%$. The application of hand washing to nurses must also be supported by the nurses' awareness in protecting themselves and patients from infectious materials as well as awareness in carrying out the correct SPO. The habit of washing hands in the hospital is a fundamental behavior in the prevention of cross infection.

In addition, the results of the study indicate an effect of infection control prevention management based on Regulation / SPO on nurses' compliance in implementing hand hygiene. This is because the SOP for infection control prevention management is in the hospital which must be carried out by nurses in carrying out nursing care. Although the majority of infection control prevention management is based on Regulation / SPO is good. But there is also infection control prevention management based on Regulations / SPO category less. The application of washing hands to nurses must also be supported by the awareness of the nurses themselves in protecting themselves and patients from infectious materials as well as awareness of implementing the correct SOP. The habit of washing the hands of nurses in the hospital is a fundamental behaviour in an effort to prevent cross infection. Nurses must comply with hand hygiene as an effort to prevent nosocomial infections in hospitals so that they can improve the quality of service.

Moreover, there is an effect of infection control prevention management based on Infection Prevention and Control (PPI) on nurses' compliance in implementing hand hygiene. This is because the hospital has an Infection Prevention and Control (PPI) team that supervises nurses in implementing hand hygiene. Although the majority is good, there is also infection control prevention management based on the Infection Prevention and Control (PPI) category lacking. If the nurse does not do hand hygiene, there is no warning from the PPI team because the PPI team only looks for the main problem in hand hygiene. If the nurse does not practice hand hygiene, then the head of the ward is warned and told to repeat it again. Often the nurses are reminded to do hand hygiene during the morning meeting and are also required to take every action, both before contact and after contact.

The results of the multivariate analysis of this study indicate that the dominant variable of respondent compliance in implementing hand hygiene in the in-patient room of RSUD Rantauprapat based on infection control prevention management, regulation, Infection Control Prevention (PPI), supervision and training that has the greatest influence is supervision because it has the largest regression coefficient (B) is 2,444 with an Exp (B) value of 11,520 , meaning that employees who carry out good category supervision of respondent compliance in implementing hand hygiene have a 11,520 times chance of implementing hand hygiene compared to employees who carry out poor category supervision of respondent compliance in implementing hand hygiene. 


\section{Conclusion}

The present study aimed at analyzing infection control prevention management on nurses' compliance in implementing hand hygiene in the in-patient rooms of Rantauprapat Hospital. The results of the study indicate that regular supervision and training serve as the most effective option in infection control prevention management. Moreover, nurses' compliance with the implementation of hand hygiene in the in-patient rooms of Rantauprapat Hospital has direct relationship with good infection control prevention management. There is also a relationship between infection control prevention management based on training on nurses' compliance in implementing hand hygiene in the inpatient room of Rantauprapat Hospital in 2020 with the results of the chi-square sig-p $=0.001$. The most dominant variable that affects nurses' compliance in implementing hand hygiene is supervision because it has the greatest regression coefficient (B), which is 2.444 with an Exp (B).

\section{Conflict of Interest}

We have no competing interests.

\section{Funding:}

The authors received no funding for conducting this study.

\section{References}

DepKes, R. I. (2008). Panduan nasionalkeselamatanpasienrumahsakit (patient safety). Depkes RI Jakarta.

Safety, W. P., \& World Health Organization. (2009). WHO guidelines on hand hygiene in health care: a summary (No. WHO/IER/PSP/2009.07). World Health Organization.

Trampuz, A., \& Widmer, A. F. (2004). Hand hygiene: a frequently missed lifesaving opportunity during patient care. In Mayo clinic proceedings (Vol. 79, No. 1, pp. 109116). Elsevier.

Tavolacci, M. P., Ladner, J., Bailly, L., Merle, V., Pitrou, I., \&Czernichow, P. (2008). Prevention of nosocomial infection and standard precautions: knowledge and source of information among healthcare students. Infection control and hospital epidemiology, 29(7), 642-647.

Manojlovich, M., \&DeCicco, B. (2007). Healthy work environments, nurse-physician communication, and patients' outcomes. American Journal of Critical Care, 16(6), 536-543.

Hinkle, J. L., \& Cheever, K. H. (2018). Brunner and Suddarth's textbook of medical-surgical nursing. Wolters kluwerindia Pvt Ltd.

Beggs, C. B. (2003). The airborne transmission of infection in hospital buildings: fact or fiction?.Indoor and built Environment, 12(1-2), 9-18.

Suleyman, G., Alangaden, G., \&Bardossy, A. C. (2018). The role of environmental contamination in the transmission of nosocomial pathogens and healthcare-associated infections. Current infectious disease reports, 20(6), 1-11. 